Article

\title{
Real Effective Exchange Rate of Rouble and Competitiveness of Russian Agrarian Producers
}

\author{
Mansoor Maitah *, Elena Kuzmenko and Lubos Smutka \\ Department of Economics, Faculty of Economics and Management, Czech University of Life Sciences, \\ Prague 165 21, Czech Republic; kuzmenko@pef.czu.cz (E.K.); smutka@pef.czu.cz (L.S.) \\ * Correspondence: maitah@pef.czu.cz; Tel.: +420-224-38-21-39 \\ Academic Editor: Ralf Fendel \\ Received: 3 March 2016; Accepted: 15 June 2016; Published: 27 June 2016
}

\begin{abstract}
A number of development projects were launched in Russia to support agro-producers, emphasizing increasing potential and perspective significance of Agrarian sector in the Russian economy. In light of this, it becomes interesting to investigate the position of agro-producers both in comparison to producers from other domestic sectors and relatively to its main foreign competitors. An analysis of the recent dynamics (from 2000 to 2014) of the real effective exchange rate of Russian rouble serves in the present study as an indicator of price competitiveness, which determines relative position of domestic producers in external markets. The actual competitive state of Russian agro-producers is analyzed by the means of revealed comparative advantage indices proposed by Balassa, Vollrath and Lafay. The calculations have shown that the entire analyzed period can be generally characterized as the period of significant real appreciation of the Russian rouble and the reason behind this is the difference in inflation rates in Russia and its main foreign trade partners. This predetermined the relatively low price competitiveness of agro-producers, which was mostly confirmed by calculated values of Balassa Revealed Comparative Advantage (RCA) index, Vollrath Revealed Competitiveness index (VRC) and Lafay Trade Specialization index (LFI). The short-term real depreciations of the rouble did not have any expected substantially positive impacts on their competitive position.
\end{abstract}

Keywords: real effective exchange rate; agrarian producers; economic sectors; competitiveness; Balassa index; Vollrath index; Lafay index; Russia

JEL Classification: F31; Q17

\section{Introduction}

The Russian government's activity aimed at regulation and support of agriculture has increased recently. The necessity of receiving by agriculture a state support, including financial support, aimed at stimulation of its efficiency growth, is determined by the characteristics of the agrarian sector. Among these characteristics can be listed the following ones: the impact of climatic factors that determine the creation and development of the insurance system with the direct participation of the state; price volatility, which depends on market conditions and is characterized by low elasticity of demand for agricultural products; a low degree of monopolization of agricultural production compared with other sectors of the economy; and lack of capital inflows into intensive agriculture, which cannot have a return on investment greater than in other areas (Shkarupa, 2010 [1]; Batmanova et al., 2014 [2]). Prominent American specialist on the Russian economy Clifford Gaddy points out that Russia's oil and gas sector will continue, for the predictable future, to be the key to the country's economic development (Gaddy, 2004 [3]). Nevertheless, the recent policy direction for reforming Russia's industrial structure should also be noted. As it is known, the Russian government has adopted a policy to target economic 
development away from heavy dependence on oil and gas (Kuboniwa, 2011 [4]). The most important events in agricultural policy during the years selected for the analysis in the present paper (from 2000 to 2014) were the national project "The Development of Agricultural Complex" (2006-2007), the Food Security Doctrine of the Russian Federation (2010), and Russia's accession to the World Trade Organization (2012). The adoption of these documents has established a new formal framework for agricultural business, and created a space for emerging possibilities to change the situation in the country's agriculture (Barsukova, 2013 [5]). Within the frameworks of these directives, a number of development projects were launched to support agrarian producers, which emphasizes the fact of increasing potential and perspective significance of the Agrarian sector in the Russian economy (Shkarupa, 2010 [1]). In light of this, it becomes interesting to investigate the competitive position of Russian Agrarian producers both in comparison to domestic producers from other sectors and in relation to its main foreign competitors. (Maitah and Smutka, 2016 [6]), (Smutka et al., 2015 [7]), (Maitah et al., 2016 [8]).

Economists employ the notion of "competitiveness" in various ways. One is exclusively macroeconomic: the absence of competitiveness is considered as a real exchange rate poser, when a country at full employment experiences "a persistent (and unwelcome) current account deficit which would in due course require adjustment, usually via a mixture of deflation and depreciation" (Boltho, 1996 [9]). The measure of competitiveness here is "relative price and/or cost indices expressed in some common currency" (Boltho, 1996 [9]). This approach implies that "underlying structural factors are constant (or irrelevant) and focuses on the kinds of short-term macroeconomic management that affect relative price of national goods and services relative to other countries" (Lall, 2001 [10]). According to economic theory, one of such macroeconomic tools enabling monitoring and the adjustment of price competitiveness of domestic producers is the real effective exchange rate (Klvačová, 2005 [11]). It is important that the real effective exchange rate does not deviate steadily and too much from its equilibrium level given by economic fundamentals so that relative prices keep near to the equilibrium over time allowing a country's external position be sustainable (Ajevskis et al., 2014 [12]).

Both fundamental characteristics of the Russian economy and external environment play a leading role in shaping the real effective exchange rate in Russia. The observed changes in the real effective exchange rate are largely caused by fluctuations in world commodity prices, and mainly crude oil prices. At the same time, the monetary authorities may to a certain extent influence the exchange rate. The former Minister of Finance in the Russian Federation Aleksey Kudrin (2006) [13] asserts that a high growth rate of national currency appreciation is dangerous for any economy, and generally governments avoid the policy of "strong" national currencies. The strongest negative impact of the rapid appreciation of the rouble is perceived by business, since the internal costs start to exceed the costs of similar products' producing in other countries. The influence of the external environment on the exchange rate of the Russian rouble was mitigated by appropriate measures of the Russian Federation's Central Bank. The main tool for solving this problem is the Bank of Russia's intervention in the currency market. When the terms of trade improve such interventions lead to an increase in foreign exchange reserves, while during the periods of declining export prices the Bank of Russia's interventions result in decline in foreign exchange reserves. In conducting the exchange rate policy, The Bank of Russia takes into account its impact on the competitiveness of Russian goods in the domestic and foreign markets. Adhering to the policy of maintaining an undervalued currency, governments thereby seek to protect their economies from foreign competition.

One of the strongest propositions of classical trade theory is that the pattern of international trade, which reflects a country's external position, is determined by comparative advantage. In other words, a country with the comparative advantage in a given commodity exports, and the other with the comparative disadvantage-imports (Sanidas, 2010 [14]). Traditionally, Revealed Comparative Advantage (RCA) indices have been used as measures, which can be interpreted in three ways. "First, they can provide a demarcation regarding whether or not a given country enjoys a comparative advantage on a given commodity (dichotomous measure); second, they can provide rankings of 
sectors within a given country in cross-sector analysis, and rankings of countries with respect to a given commodity in cross-country analysis (ordinal measure); lastly, they can quantify the degree of comparative advantage enjoyed by a given country with respect to a given commodity (cardinal measure)" (Ballance et al., 1987 [15]). Accordingly, a few ways of using the RCA indices exist in order to analyze a country's trade performance. The most common way is to "make a comparison across sectors within a given country or across countries with respect to a given sectors by using rankings in order of the calculated index values or to examine how much of comparative advantage or disadvantage a given country gained during the period of interest by directly comparing the calculated index values" (Sanidas, 2010 [14]). "The main aim of competitiveness strategy is to help countries to realize or build dynamic comparative advantage ... what assumes that static advantages based on existing factor endowments are already fully realized" (Lall, 2001 [10]). The important question that then arises is what the conditions are under in which such strategies can be established successfully. In order to try to answer this question, one needs first to analyze the current state of affairs in that field in a country reflected by the following (among others) macroeconomic indicators: real effective exchange rate of local currency unit (LCU), and RCA indices, which take into account both export and import flows of different commodity groups.

Everything mentioned above predetermined the main aim of the present paper: to analyze the recent dynamics (from 2000 to 2014) of the real effective exchange rate of the Russian rouble and compare its evolution with the position of Russian Agrarian producers (along with other producers of selected commodity groups) in corresponding internal and external markets. The internal market position is represented in the present study by market share of Russian producers in domestic markets. The position of domestic producers in corresponding external markets is reflected by Balassa, Vollrath and Lafay indices of the key commodity groups of the Russian Federation's foreign trade flows.

\section{Methodology}

The methodology of the present study, being based on the main propositions of the Classical trade theory and Keynesian theory of exchange rate, employs correspondingly both foreign trade performance indicators and real effective exchange rate index. Thus, in order to achieve the main goal of the present paper, i.e., to analyze the recent dynamics (from 2000 to 2014) of the real effective exchange rate of Russian rouble (REER) and compare its evolution with the dynamics of competitive position of Russian agrarian producers (along with other selected sectors' producers) in corresponding internal and external markets, the research will consist of the following three main sections:

1. The calculation of the real effective exchange rate of Russian rouble.

2. The analysis of Russian agro-producers' competitiveness in internal markets. This section, in turn, consists of two subsections:

- the calculation of average annual growth rates of industrial manufacturing (selected commodity groups) in Russia and average annual growth rates of corresponding Russian imports;

- the calculation of domestic producers' (selected commodity groups) market share.

3. The analysis of Russian agro-producers' competitiveness in external markets.

This section deals with calculation of Balassa Revealed Comparative Advantage Index, Vollrath Revealed Competitiveness Index and Lafay trade specialization index. These three methodological parts are described in more detail below.

\subsection{The calculation of the Real Effective Exchange Rate of Russian Rouble}

According to the methodology of the Russian Federation's Central Bank, when constructing the real effective exchange rate index to a basket of foreign currencies, currencies of those foreign trade-partners have to be taken into account, the weight of which in total foreign trade turnover is not 
less than $0.5 \%$. The number of these countries over the period under analysis was around 30 and their share counted for slightly more than $85 \%$ in total Russia's foreign trade turnover. Some of Russia's most important foreign trade partners are listed in the Table A1 (see Appendix A). Selected countries are grouped according to their membership in a particular economic/regional block.

However, the vast majority of these countries' currencies accounts for a very insignificant share on Russian currency market. Taking into account the fact that payment for the supply of main exported by Russia products is carried out in USD, namely the USD takes the dominating position on the Russian currency market. At the same time, "the average total share of Euro in currency turnover of Moscow Interbank Currency Exchange was $2.6 \%$ in 2007, whereas the share of Euro in the basket of foreign currencies accounts for up to 44.5\%" (Panilov, 2009 [16]).

For these reasons, the construction of REER in the present study was done on the basis of both USD and EUR currencies. The corresponding weights will be calculated as total turnover of USD/RUR and EUR/RUR in Moscow Interbank Currency Exchange. Equation for calculation of REER is given below:

$$
R E E R_{m}=\prod_{i=1}^{n}\left(\frac{P_{m}}{P_{m}^{k}} \cdot \frac{N E R M_{m}^{k}}{N E R M_{m-1}^{k}}\right)^{w_{m}^{k}}
$$

where $R E E R_{m}$ is the monthly real effective exchange rate to USD and EUR; $P_{m}$ is a price index that demonstrates the ratio of inflation rate for the month- $m$ to previous month- $(m-1)$ in Russia; $P_{m}{ }^{k}$ is the same index for country- $k ; N E R M_{m}{ }^{k}$ is the monthly average nominal exchange rate of Russian rouble (indirect quotation) to $k$-currency in month- $m$; NERM $m_{m-1}{ }^{k}$ is the same for the previous month- $(m-1)$; $w_{m}{ }^{k}$ is normalized monthly weight of $k$-currency; $n=2$ (USD and EUR); and $k$ is country (implies USA and EU).

If the calculated value of REER index is higher than unity it means the growth of index relative to the previous month and vice versa. The growth and decline in index values are expressed in percentages. The level of the previous month was taken as $100 \%$ so that a percentage growth/decline in REER index values was calculated as $\left(R E E R_{m}-1\right) \times 100 \%$. REER index curve measured in percentages is then calculated with the use of the following equation:

$$
\operatorname{REER}_{m}(\%)=\operatorname{REER}_{m-1}(\%)-\left(\operatorname{REER}_{m}-1\right) \times 100 \%
$$

According to the Equation (1), the REER index is influenced by the values of inflation rate (expressed as Consumer Price Index) $P_{m}, P_{m}{ }^{k}$ and nominal exchange rate index $N E R_{m}{ }^{k}$. Thus, the resulting value of the REER index can be rewritten as:

$$
\operatorname{REER}_{m}=\operatorname{REER}\left(P_{m}\right) \times \operatorname{REER}\left(N E R_{m}\right)
$$

where REER $\left(P_{m}\right)$ is a REER index purified from $N E R_{m}$ influence (or when $N E R_{m}$ is constant), but influenced by changes in inflation rate; and REER $\left(N E R_{m}\right)$ is a REER index purified from $P_{m}$ influence (or when $P_{m}$ is constant), but influenced by changes in Nominal exchange rate index.

Following the same logic as in Equation (1), we get:

$$
\begin{gathered}
\operatorname{REER}\left(P_{m}\right)=\prod_{k=1}^{n}\left(P_{m} / P_{m}^{k}\right)^{w_{m}^{k}} \\
\operatorname{REER}\left(N E R_{m}\right)=\prod_{k=1}^{n}\left(N E R_{m}^{k}\right)^{w_{m}^{k}}
\end{gathered}
$$


Calculation of percentage changes in $\operatorname{REER}\left(P_{m}\right)$ and $R E E R\left(N E R_{m}\right)$ is conducted in the same way as it was suggested by Equation (2):

$$
\begin{gathered}
\operatorname{REER}\left(P_{m}, \%\right)=\operatorname{REER}\left(P_{m-1}, \%\right)-\left(\operatorname{REER}\left(P_{m}\right)-1\right) \times 100 \% \\
\operatorname{REER}\left(\operatorname{NER} R_{m-1}, \%\right)=\operatorname{REER}\left(N E R_{m-1}, \%\right)-\left(\operatorname{REER}\left(N E R_{m}\right)-1\right) \times 100 \%
\end{gathered}
$$

Using Equations (2) and (3), we get:

$$
\operatorname{REER}_{m}(\%)=\operatorname{REER}_{m-1}(\%)-\left(\operatorname{REER}\left(P_{m}\right) \times \operatorname{REER}\left(N E R_{m}\right)-1\right) \times 100 \%
$$

In accordance with Panilov (2009) [16], since $(x-1) \times(y-1)=x \times y-x-y+1$, then for any $x$ and $y$ the following identity is true: $x \times y=x+y-1+(x-1) \times(y-1)$.

If $x$ and $y$ values differ little from unity, then the following approximate equation is true:

$$
x \times y \approx x+y-1
$$

The error for Equation (9) expressed in percentages is then: $((x-1) \times(y-1)) / 100 \%$. Error values become significant, in case if $(x-1)$ and $(y-1)$ equal to $10 \%$ or more (Orlov, 2002).

Taking into account that REER $\left(P_{m}\right)$ and $R E E R\left(N E R_{m}\right)$ do not exceed $5 \%$, we can consequently assert that:

$$
\operatorname{REER}\left(P_{m}\right) \times \operatorname{REER}\left(\operatorname{NER} R_{m}\right) \approx \operatorname{REER}\left(P_{m}\right)+\operatorname{REER}\left(N E R_{m}\right)-1
$$

Substituting expression Equation (10) into Equation (8), we get:

$$
\operatorname{REER}_{m}(\%) \approx \operatorname{REER} R_{m-1}(\%)-\left(\operatorname{REER}\left(P_{m}\right)+\operatorname{REER}\left(N E R_{m}\right)-2\right) \times 100 \%
$$

If we consider the right part of the Equation (11) separately and simplify it using Equations (6) and (7), we get: $R E E R_{m-1}(\%)-\left(\operatorname{REER}\left(P_{m}\right)+\operatorname{REER}\left(N E R_{m}\right)-2\right) \times 100=R E E R\left(P_{m-1}, \%\right)-(R E E R$ $\left.\left(P_{m}\right)-1\right) \times 100+\operatorname{REER}\left(N E R_{m-1}, \%\right)-100-\left(\operatorname{REER}\left(N E R_{m}\right)-1\right) \times 100=\operatorname{REER}\left(P_{m}, \%\right)+R E E R$ $\left(N E R_{m}, \%\right)-100$.

Thus, REER index where influences of inflation and nominal exchange rate are separated can be written as:

$$
\operatorname{REER}_{m}(\%) \approx \operatorname{REER}\left(P_{m}, \%\right)+\operatorname{REER}\left(N E R_{m}, \%\right)-100
$$

Equations (3)-(12) show the logic according to which the initial Equations (1) and (2) were represented the way allowing distinguishing influences exerted by inflation rate and nominal exchange rate on REER. This decomposition helps to see what factor was the strongest cause of the real effective exchange rate appreciation or depreciation. Taking into account the fact that one of the partial aims of the research is to analyze the recent dynamics of the real effective exchange rate of Russian rouble, the decomposition analysis is seen as justified since it shed some light on the roots of REER fluctuations. The results of the calculations are presented in Figure 1 (see Section 3).

\subsection{Analysis of Russian Agro-Producers' Competitiveness in Internal Markets}

For a meaningful assessment of any phenomenon development in time, a number of various analytical indicators can be used. One of the most common among them is the average growth rate. The average annual growth rate in industrial manufacturing of selected groups of commodities in the Russian economy as well as the average rate of increase in imports of corresponding groups of commodities is calculated in the present study employing a standard statistical approach for a time series. The period for the analysis is from 2000 to 2014 . The obtained values will then be compared. The results of that comparison are given in Table 2 (see Section 3.1). 
The equation used for the calculation of the average growth rate is as follows:

$$
G R A_{G O}^{i}=\left(\left(G O_{t}^{i} / G O^{i}{ }_{t 0}\right)^{1 / n}-1\right) \times 100 \%
$$

where GRA is average growth rate expressed in \%; $G O_{t}$ is gross output in sector $i$ in 2014; $G O_{t 0}$ is gross output in sector $i$ in 2000; and $n$ is number of observations with the same periodic in the selected period (in our case $n=15$ ).

The same approach was employed for calculation of the average rate of increase in imports:

$$
G R A_{I M}^{i}=\left(\left(I M^{i} t / I M^{i}{ }_{t 0}\right)^{1 / n}-1\right) \times 100 \%
$$

The methodology for calculating market share of domestic producers used in the present research is based on the study of Blank, Gurvich and Ulyukaev (2006) [17]. To calculate the share of domestic producers in corresponding internal markets the following data will be used: the volumes of industrial production by selected Equation (9) commodity groups representing corresponding types of economic activity (values are expressed in Russian roubles (RUR)), data on imports and exports of the same commodity groups (raw data were expressed in US dollars and then with the use of corresponding to each period exchange rates were converted to RUR). These data allow for the estimation of the domestic supply $\left(S_{i}\right)$ and domestic demand $\left(D_{i}\right)$ volumes:

$$
\begin{gathered}
S_{i}=Y_{i}-E x_{i} \times e \\
D_{i}=S_{i}+I m_{i} \times e
\end{gathered}
$$

where $Y_{i}$ is volumes of production in $i$-commodity group; $E x_{i}$ and $I m_{i}$ are volumes of exports and imports of $i$-commodity group (in USD), respectively; and $e$ is the RUR/USD nominal exchange rate.

The share of domestic producer in corresponding internal market is then calculated with the use of the following ratio:

$$
v_{i}=S_{i} / D_{i}
$$

The obtained results are presented in Table 3 (see Section 3.2).

\subsection{Analysis of Russian Agro-Producers' Competitiveness in External Markets}

The classical theory of comparative advantage predicted that gains from the exchange of goods maximize welfare and free trade would lead to world economic prosperity. The determinants of the comparative advantage, however, differ among various trade theories. The Ricardian theory, for instance, explains comparative advantage from costs and technological differences, the Heckscher-Ohlin-Samuelson theory considers factors' price differences, the theory of product cycle examines technological innovation, neo-technological theory looks at factor efficiency, but considers a learning-by-doing effect (soft technological change) as the main cause of comparative advantage differences. Comparative advantage faces a measurement problem, as it is defined in terms of autarkic price relationships that are not observable. Trade statistics reflect only post-trade situations (Bender and Li, 2002 [18]). The revealed comparative advantage (RCA) approach, pioneered by Balassa (1965) [19], assumes that the true pattern of comparative advantage can be observed from post-trade data only. Balassa RCA compares the export share of a given sector in a country with the export share of that sector in the world market. The RCA index is calculated as follows (Balassa, 1965 [19]):

$$
R C A=\left(X_{i j} / X_{i t}\right) /\left(X_{n j} / X_{n t}\right)=\left(X_{i j} / X_{n j}\right) /\left(X_{i t} / X_{n t}\right)
$$

where $X_{i j}$ is exports of $j$-commodity from $i$-country; $n$ is a set of countries; and $t$ is a set of commodities.

RCA index is based on export performance and existing trade patterns. It measures a country's exports of a commodity relative to its total exports. Thus, if RCA $>1$, then a comparative advantage 
is revealed. Up to the present time, the Balassa's RCA index was the most common method of calculating the comparative advantages (Svatoš and Smutka, 2012 [20]). It served as a base for later developments of new, more relevant to modern economic realities indices. Among later alternative attempts to measure comparative advantage the following most popular indices can be listed: Vollrath Competitive index (VCA) and Lafay index.

According to the approach suggested by Vollrath, the revealed competitiveness (RC) is calculated as the logarithm of the relative export advantage $(\ln R X A)$ minus the logarithm of the relative import advantage $(\ln R M A)$. It is expressed as:

$$
V R C=R C=\ln R X A-\ln R M A
$$

where $R X A$ equals to Balassa $R C A$ index, and $R M A$ is calculated on the basis of the Equation (18), but, instead of export flows, imports are considered.

Values greater than zero reveal a comparative advantage; alternatively, negative values reveal a comparative disadvantage (Vollrath, 1991 [21]).

The next indicator, which was proposed by Lafay (1992) [22], measures the extent of a country's specialization in a given sector in international dimension. The Lafay index (LFI), by taking into account imports, allows for control of intra-industry trade and re-export flows. LFI index weights each product's contribution according to the respective importance in total trade. For a given country $i$, and for any given product $j$ ( $N$, is a selected set of products), the Lafay index is defined as:

$$
L F I_{j}^{i}=100\left(\frac{x_{j}^{i}-m_{j}^{i}}{x_{j}^{i}+m_{j}^{i}}-\frac{\sum_{j=1}^{N}\left(x_{j}^{i}-m_{j}^{i}\right)}{\sum_{j=1}^{N}\left(x_{j}^{i}+m_{j}^{i}\right)}\right) \frac{x_{j}^{i}+m_{j}^{i}}{\sum_{j=1}^{N}\left(x_{j}^{i}+m_{j}^{i}\right)}
$$

where $x_{j}^{i}$ and $m^{i}{ }_{j}$, are, respectively, exports and imports of $j$-commodity from $i$-country.

Using this index, we consider the difference between each item's normalized trade balance and overall normalized trade balance (Smutka et al., 2014 [23]). Given that the index measures each group's contribution to the overall normalized trade balance, the following relation holds: $\sum_{j=1}^{N} L F I_{j}^{i}=0$. Positive values of the Lafay index indicate the existence of comparative advantages in a given item; the larger the value is the higher the degree of specialization. On the contrary, negative values point to de-specialization (Zaghini, 2003 [24]).

\section{Results and Discussion}

Figure 1 illustrates the calculations on REER of RUR index to EUR-USD currencies (REER_EUR-USD) along with REER indices reflecting separate influences of inflation rate changes (REER_EUR-USD_P) and nominal exchange rate changes (REER_EUR-USD_NER) on REER_EUR-USD. The downward slope of the REER index curve corresponds to the REER growth, i.e., RUR appreciation with regard to EUR-USD currency pair, and vice versa.

The first thing that deserves attention is that the observed dynamics of REER index curve confidently points to the real appreciation of the domestic currency. The latter at the end of the analyzed period compared to the beginning amounted to approximately $56 \%$. However, in 2013 , the real appreciation of the Russian rouble achieved even more dramatic values of $94 \%$. The recovery of the REER of RUR (its depreciation) in the last analyzed year, 2014, was due to a sharp decline in the nominal exchange rate of RUR in relation to EUR-USD currency pair. 


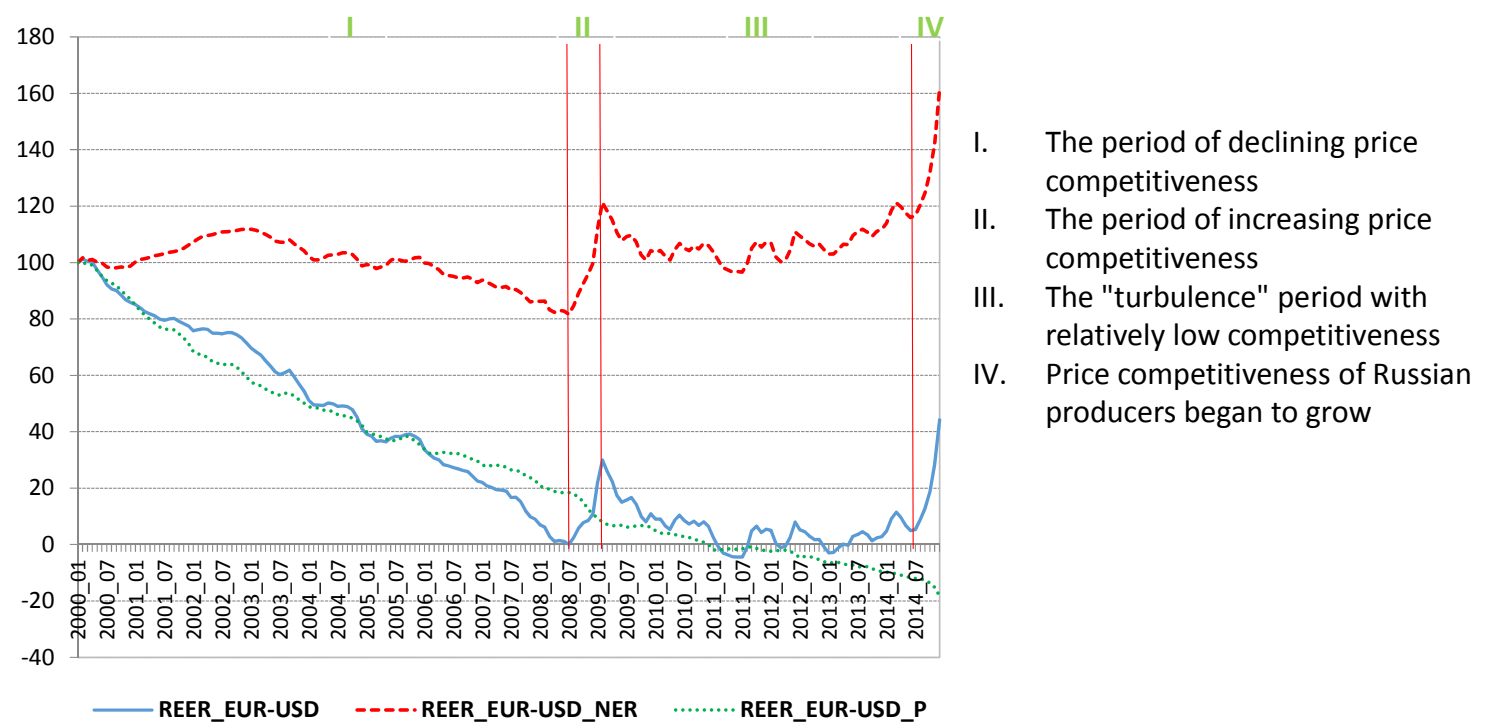

Figure 1. The REER of rouble to a basket of USD-EUR currencies ${ }^{1}$ (2000-2014), in \%. Note: ${ }^{1}$ REERindex is CPI adjusted and the total turnover of USD/RUR and EUR/RUR currency pairs weighted. Source: Author's calculation, raw data taken from: www.micex.ru [25] and https://www.statbureau.org [26,27].

Still, in 2009, the impact of the world financial crisis made the Russian monetary authorities pass "Basic directions of general state monetary and credit policy for 2009 and for the period of 2010-2011" in late October 2008. The policy of mild depreciation of the rouble exchange rate ended in March 2009 with achieving the currency band at RUR 38-41 per the USD/EUR basket compared to RUR 29-30 per the basket in September 2008. The mentioned basket consists of USD 0.55 and EUR 0.45. In early 2010, the Russian Federation monetary authorities made the currency band floating and it reached RUR 33.7-36.7 per the basket in April 2010 due to the rise in world prices of Russian major export commodities" (according to the All-Russian Market Research Institute' report [28]). With regard to the latest situation, a floating exchange rate regime is currently underway in Russia. "Effective from 10 November 2014, the Bank of Russia abolished the exchange rate policy mechanism through cancelling the permissible range of the dual-currency basket rouble values (operational band) and regular interventions on and outside the borders of this band. However, the new approach of the Bank of Russia to operations in the domestic market does not provide for complete abandonment of foreign exchange interventions, which can be implemented in case of financial stability threats ... As a result of the implementation of this decision, the rouble exchange rate will be determined by the market factors that should enhance the efficiency of the Bank of Russia monetary policy and ensure price stability. Besides, the new approach to operations in the domestic Foreign Exchange market will contribute to faster adjustment of the economy to changes of external conditions and enhance its resistance to negative shocks" (The Central Bank of the Russian Federation (Bank of Russia), 2014 [29]). This implies that the exchange rate of the rouble is not fixed and there are no targets set for the exchange rate corridor or its fluctuations. Under normal conditions, the Bank of Russia does not intervene to affect the exchange rate of rouble. Nevertheless, in case of necessity and in order to maintain financial stability, the Bank of Russia monitors developments in the Foreign Exchange market and may resort to foreign exchange operations.

The results of the real effective exchange rate of Russian rouble calculation have shown that its influence in accordance with the theory is expected to be unfavorable in relation to domestic producers since real appreciation affects price competitiveness of the latter negatively. The observed dynamics of REER_EUR-USD index allows us to conclude that RUR gradually appreciated from January 2000 to July 2008. The real appreciation of the RUR during that period amounted to approximately $97 \%$ (period I). However, in nominal terms the appreciation of RUR amounted to nearly $18 \%$ at the end 
of the same period. In the next period II, RUR demonstrated a depreciation; the latter lasted up to February 2009 and amounted to approximately 40\% relatively to its value at the end of the previous period in nominal terms and around $28 \%$ in real terms. After that, the dynamics of the REER_EUR-USD index curve can be characterized as turbulent with a declining overall trend (period III). It implies that during this period RUR again began to appreciate in real terms.

The real appreciation of RUR in the period III approximately amounted to $25 \%$ relatively its value at the end of the period II; however, values of the nominal effective exchange rate of RUR were at the end of the same period almost identical to those in the beginning. The next period IV demonstrates a sharp growth of REER_EUR-USD index, which means RUR real depreciation.

Decomposition of inflation' and NER' influences on REER has shown that the greatest impact on REER appreciation was exerted by the difference in inflation rates in Russia and its main foreign trade partners (on currency market). Nominal exchange rate fluctuations affected REER to a much lower extent than it inflation rate did (see Table 1).

Table 1. Contributions of inflation (REER_P) and nominal exchange rate (REER_NER) to change in REER $^{1}$, in \%.

\begin{tabular}{cccc}
\hline Year & REER & REER_NER & REER_P \\
\hline 2000 & 15.10 & 8 & 92 \\
2001 & 8.64 & 30 & 70 \\
2002 & 5.99 & 31 & 69 \\
2003 & 18.48 & 47 & 53 \\
2004 & 13.89 & 42 & 58 \\
2005 & 3.94 & 29 & 71 \\
2006 & 15.80 & 61 & 39 \\
2007 & 14.24 & 50 & 50 \\
2008 & -1.94 & 51 & 49 \\
2009 & -1.59 & 56 & 44 \\
2010 & 4.27 & 23 & 77 \\
2011 & 0.63 & 41 & 59 \\
2012 & 6.08 & 38 & 62 \\
2013 & -3.69 & 66 & 34 \\
2014 & -35.55 & 82 & 18
\end{tabular}

Note: ${ }^{1}$ REER - the real effective exchange rate of Russian rouble. Values of REER index, calculated as it average change in corresponding year relatively to the previous one, are also given in $\%$. Positive values correspond to REER index growth (i.e., rouble appreciation). Source: Author's calculation.

According to Brodsky (2006) [30], real appreciation of the national currency reduces competitiveness of all domestic producers and entails a number of other negative consequences. In particular, REER appreciation reduces gross outputs as well as exports of manufacturing industries. It eventually leads to unemployment growth, increase in imports, declining net exports and, ultimately, a drop in the volume of the gross domestic product. Increase in imports is another alarming symptom of a declining national competitiveness. In the next subsection, namely the interrelation between production volumes and volumes of imports will be analyzed.

\subsection{Competitiveness of Russian Agro-Producers in Internal Markets}

To investigate the position of Russian agro-producers in internal markets relative to both its foreign competitors and domestic producers representing other sectors, it was decided to estimate their market shares in corresponding markets. Prior to that, it was necessary to collect data both on volumes of production and corresponding export and import flows. Table 2 given below presents the results of the calculations of average annual growth rates of production volumes in comparison to average growth rates of corresponding imports (Equations (13) and (14) were used).

According to the obtained results, we can conclude that during the analyzed period, the average annual growth rates of production volumes in almost all sectors (except Mineral Products) were 
much lower in comparison to average growth rates of corresponding imports. Negative difference $\left(D_{i f}\right)$ between corresponding values of gross outputs and imports emphasizes a high rate of import volumes' growth that exceeds the growth rate of corresponding gross output volumes. It may imply an increasing dependency of the Russian economy on imports. A similar assertion was made by Kudrin (2006) [13] based on the results of the regression analysis of the data for the period from 1996 to 2006. The highest difference between output and import growth rates was observed in the following markets (they are listed in descending order): Textiles, Textile Products and Footwear; Hides and Skins, Furs and Products from them; Machinery, Equipment and Vehicles.

However, despite negative $D_{i f}$ value, relatively good results in comparison to all other sectors were revealed for "Foodstuffs and agricultural raw materials (except textile)"; that is, namely for agro-producers. In other words, the position of agro-producers among other selected sectors' producers in domestic markets is one of the best (after Mineral Products).

Table 2. Average annual growth rates of production volumes in comparison to average growth rates of corresponding imports for the period from 2000 to 2014 .

\begin{tabular}{|c|c|c|c|c|c|c|c|c|c|}
\hline & $\begin{array}{l}\text { Foodstuffs and } \\
\text { Agricultural } \\
\text { Raw Materials } \\
\text { (Except Textile) }\end{array}$ & $\begin{array}{l}\text { Mineral } \\
\text { Products }\end{array}$ & $\begin{array}{l}\text { Chemical } \\
\text { Products, } \\
\text { Rubber }\end{array}$ & $\begin{array}{l}\text { Hides and } \\
\text { Skins, Furs } \\
\text { and Products } \\
\text { from Them }\end{array}$ & $\begin{array}{l}\text { Timber and } \\
\text { Pulp and } \\
\text { Paper } \\
\text { Products }\end{array}$ & $\begin{array}{l}\text { Textiles, } \\
\text { Textile } \\
\text { Products } \\
\text { and } \\
\text { Footwear }\end{array}$ & $\begin{array}{l}\text { Precious } \\
\text { Metals, } \\
\text { Precious } \\
\text { Stones and } \\
\text { Products } \\
\text { from Them }\end{array}$ & $\begin{array}{l}\text { Metals } \\
\text { and } \\
\text { Products } \\
\text { from } \\
\text { Them }\end{array}$ & $\begin{array}{c}\text { Machinery, } \\
\text { Equipment } \\
\text { and } \\
\text { Vehicles }\end{array}$ \\
\hline$G R A_{\mathrm{GO}}^{i}$ & 2.31 & 8.38 & 4.13 & -1.36 & 2.02 & -3.96 & $0.32 *$ & $-1.71^{*}$ & 4.00 \\
\hline$G R A^{i}{ }_{\mathrm{IM}}$ & 3.57 & -3.11 & 9.33 & 11.69 & 3.86 & 10.00 & $7.95^{*}$ & $2.73 *$ & 11.86 \\
\hline
\end{tabular}

Note: $G R A_{\mathrm{GO}}^{i}$ - the average annual growth rate in industrial manufacturing (gross output) of selected group of commodities, $G R A^{i}{ }_{\mathrm{IM}}$ - the average annual growth rate of corresponding imports, $D_{\text {if }}$ - the difference between corresponding values of gross outputs and imports. Figures marked with "**" are calculated for the period from 2005 to 2014. Source: Author's calculations, raw data taken from: http://www.gks.ru/ [31], http://stat.wto.org [32] and http://www.customs.ru [33].

The position of Russian agro-producers along with other selected sectors' producers in domestic markets in relation to its foreign competitors was then estimated as their market share in corresponding markets. Assessment was done with the use of Equations (15)-(17). The closer a market share of a domestic producer to $100 \%$, the more competitive a position of this producer is towards to its foreign competitors within the frameworks of the selected internal market. As we can see from the Table 3 given below, the estimated shares of domestic agro-producers in internal markets were during the all analyzed period almost the same. This reveals their relatively stable position (values of market shares fluctuated between $76 \%$ and $74 \%$ ). The dynamics of other domestic producers' market shares differ among various sectors (types of economic activities). However, the most common trend for the majority of values is to decline. The highest current market shares of Russian producers are observed in the following internal markets (listed in a descending order): Precious metals, precious stones and products from them, Mineral Products, Metals and Products from them, Timber and Pulp and Paper products, Foodstuffs and Agricultural Raw Materials (Except Textile). During the analyzed period the highest increase in the market share of Russian producers was recorded in the market of Mineral Products: from $75 \%$ in 2000 to $94 \%$ in 2014; that is, $+19 \%$. The highest decline in the market share of domestic producers was recorded simultaneously in several internal markets: Machinery, Equipment and Vehicles (-24\%); Hides and Skins, Furs and Products from them $(-22 \%)$; Textiles, Textile Products and Footwear $(-22 \%)$.

Such a dramatic change in these sectors' positions (and especially in Machinery, Equipment and Vehicles between 2000 and 2005) can be explained by a large-scale crisis that struck manufacturing in Russia long before the financial shock of 2008-2009. The symptoms of this crisis, reflected by the average annual employment rate in industry, appeared in Machinery manufacturing already in 2003-2004. The reduction in employment recorded in this industry (excluding the production of arms and ammunition) was from 50.7\% to 39.6\% (Domnich, 2011 [34]). The matter is that still 
in 1998-1999 years after a sharp change in the ratio between the Russian rouble and the US dollar and consequent release of significant market niches by greatly risen in price imports, in Russia was recorded the rise in machinery production which was characterized by the following indicators: $2000-120 \%$; 2001-107.2\%; and 2002-102\% (in relation to the previous year). However, by 2002 the rate of production again fell below the average for the industry. Other factors, such as the number of loss-making enterprises, the ratio of exports and imports etc. have returned to pre-crisis levels. In fact, a resource of positive impulse for the Machinery, Equipment and Vehicles received in 1998 was fully exhausted.

Thus, we can conclude that the position of domestic agro-producers in internal markets compared to positions of domestic producers from other selected sectors can be characterized as stable and relatively favorable (see Tables 2 and 3). At the same time, in order to make a comprehensive estimate of any sector's competitive position the obtained results are not sufficient. As a matter of fact, if any sector aims to gain, in the long-term, as strong a position in a market as possible, it should make emphasis on increasing its competitiveness in international dimension. For that reason import-substitution strategy is not reliable enough in contrast to an export-oriented one. Thus, the investigation of Russian agro-producers' competitiveness in external markets is analyzed in the next sub-section.

Table 3. The estimated share of domestic producers in internal markets (2000, 2005-2014), in \%.

\begin{tabular}{|c|c|c|c|c|c|c|c|c|c|c|c|c|}
\hline $\begin{array}{l}\text { HS } \\
\text { Code }\end{array}$ & Commodity Sector & 2000 & 2005 & 2006 & 2007 & 2008 & 2009 & 2010 & 2011 & 2012 & 2013 & 2014 \\
\hline $01-24$ & $\begin{array}{l}\text { Foodstuffs and Agricultural Raw } \\
\text { Materials (Except Textile) }\end{array}$ & $74 \%$ & $75 \%$ & $74 \%$ & $74 \%$ & $75 \%$ & $76 \%$ & $74 \%$ & $74 \%$ & $74 \%$ & $74 \%$ & $73 \%$ \\
\hline $25-27$ & Mineral Products & $87 \%$ & $77 \%$ & $86 \%$ & $91 \%$ & $73 \%$ & $95 \%$ & $93 \%$ & $95 \%$ & $92 \%$ & $96 \%$ & $94 \%$ \\
\hline $28-40$ & Chemical Products, Rubber & $59 \%$ & $52 \%$ & $51 \%$ & $54 \%$ & $54 \%$ & $54 \%$ & $54 \%$ & $55 \%$ & $52 \%$ & $50 \%$ & $49 \%$ \\
\hline $41-43$ & $\begin{array}{l}\text { Hides and Skins, Furs and } \\
\text { Products from them }\end{array}$ & * & $63 \%$ & $60 \%$ & $57 \%$ & $52 \%$ & $57 \%$ & $50 \%$ & $47 \%$ & $41 \%$ & $41 \%$ & $41 \%$ \\
\hline $44-49$ & $\begin{array}{l}\text { Timber and Pulp and } \\
\text { Paper Products }\end{array}$ & * & $73 \%$ & $75 \%$ & $76 \%$ & $77 \%$ & $77 \%$ & $78 \%$ & $78 \%$ & $81 \%$ & $80 \%$ & $77 \%$ \\
\hline $50-67$ & $\begin{array}{l}\text { Textiles, Textile Products } \\
\text { and Footwear }\end{array}$ & * & $49 \%$ & $47 \%$ & $38 \%$ & $35 \%$ & $36 \%$ & $34 \%$ & $30 \%$ & $26 \%$ & $27 \%$ & $27 \%$ \\
\hline 71 & $\begin{array}{l}\text { Precious Metals, Precious Stones } \\
\text { and Products from them }\end{array}$ & $*$ & $97 \%$ & $98 \%$ & $98 \%$ & $98 \%$ & $98 \%$ & $98 \%$ & $97 \%$ & $97 \%$ & $96 \%$ & $95 \%$ \\
\hline $72-83$ & Metals and Products from them & $*$ & $83 \%$ & $83 \%$ & $82 \%$ & $82 \%$ & $83 \%$ & $83 \%$ & $84 \%$ & $80 \%$ & $80 \%$ & $81 \%$ \\
\hline $84-90$ & $\begin{array}{l}\text { Machinery, Equipment } \\
\text { and Vehicles }\end{array}$ & $74 \%$ & $55 \%$ & $52 \%$ & $50 \%$ & $46 \%$ & $52 \%$ & $52 \%$ & $52 \%$ & $50 \%$ & $52 \%$ & $50 \%$ \\
\hline
\end{tabular}

Note: *, no data available. Source: Author's calculation, raw data taken from: http://www.gks.ru [31], http:/ / stat.wto.org [32] and http:/ /www.customs.ru [33].

\subsection{Competitiveness of Russian Agro-Producers in External Markets}

The position of domestic agro-producers in corresponding external markets is reflected in the present study by Balassa, Vollrath and Lafay indices. The logic behind applying all of these three indices simultaneously is that each of them reflects different aspects of competitiveness. The Balassa index, dealing with export flows, reveals an absolute comparative advantage of a country in its foreign trade; Vollrath index, taking into account not only exports but also imports flows, reveals in turn a relative comparative advantage; Lafay index, calculation of which being based on overall normalized trade balance, points to a country's observed foreign trade specialization.

The values of these indices (Balassa, Vollrath and Lafay) were calculated on the basis of the Russian Federation's foreign trade flows. To have a possibility to compare the relative position of agro-producers in external markets not just towards to foreign rivals but also in relation to the position of domestic producers from other sectors, the mentioned indices were calculated both for agrarian trade 
and simultaneously for other selected commodity groups. Prior to the mentioned indices calculation, data on Russian exports and imports by corresponding sectors (groups of commodities) along with respected data of main Russian foreign trade partners were collected and grouped in accord with Table 1. Thus, the external market was considered in the present study in the several ways: as the external market represented by all main foreign trade partners selected for the analysis together (all trade partners) and the external markets represented by the groups of these countries separately (European Union, BRICS, and Commonwealth Independent States).

First, the Balassa RCA index was calculated with the use of Equation (18) to compare export share of the selected sector in the Russian Federation's foreign trade with export share of the corresponding sector in external markets. Figure 2 given below depicts graphically the obtained values of RCA within the frameworks of selected commodity groups.
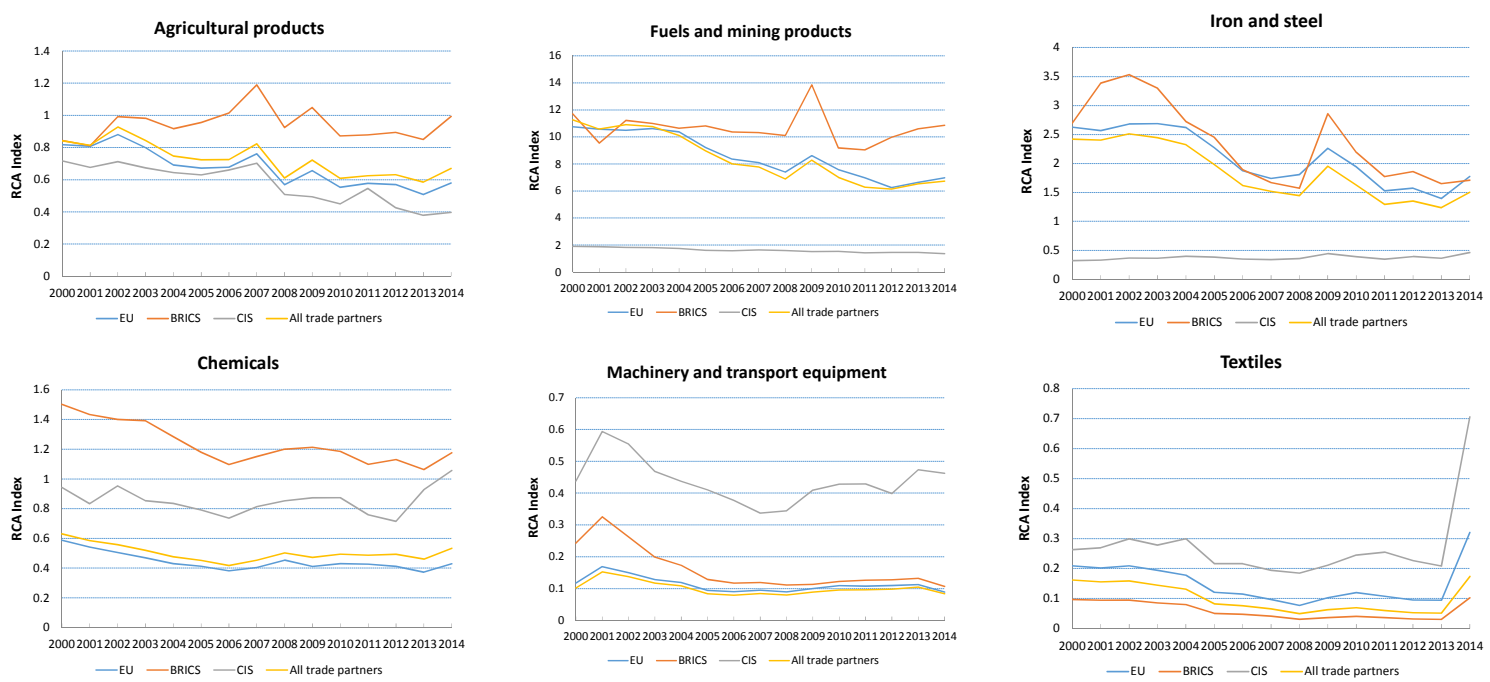

Figure 2. Balassa index by commodity groups and groups of trade partners (2000-2014). Source: Author's calculation, raw data taken from: http://stat.wto.org [32].

In accord with the methodology: if RCA $>1$, then a comparative advantage is revealed. From the Figure 2 it can be seen that RCA values of Russian exports differ significantly depending on both the commodity group and on the trade partner. Dynamics of the RCA index for Agricultural products appeared varied in relation to different foreign trade partners: with regard to BRICS group The RCA index achieved values greater than unity in 2006, 2007 and 2009, very close to unity values that were achieved in 2002, 2003 and 2014; with regard to the rest partners Russian Agrarian export demonstrated comparative disadvantage; moreover, the dynamics of the RCA index is negative. The most evidently high values of RCA are observed for Fuels and mining products, at that it amounted to several times higher values in relation to EU, BRICS and all trade partners than it did for CIS. The comparative advantage of Russian Iron and steel exports also was revealed in relation to EU, BRICS and All trade partners, but in relation to CIS group RCA index was during the all analyzed period below the unity, demonstrating, thus, a comparative disadvantage. Comparative advantage of Russian Chemicals appeared as revealed in relation to BRICS only. In 2014 greater than unity value of RCA was recorded in relation to CIS as well. Despite a sharp increase in RCA index for Russian Textiles was observed in 2014, all values of Balassa RCA index for Russian Textiles as well as for Machinery and transport equipment were less than unity through the all analyzed period demonstrating a decreasing trend in relation to all four groups of partners.

Thus, on average, the position of Agricultural Products in comparison to other groups of commodities in corresponding external markets, expressed by RCA index, appeared on the fourth place after Fuels and Mining products, Iron and Steel and Chemicals. 
Then, employing Equation (19), the Vollrath revealed competitiveness index was calculated for the same groups of commodities and in relation to the same four groups of partners. The VRC index, taking into account not only exports but also imports flows, reveals, in contrast to Balassa absolute advantage, relative comparative advantage. The Figure 3 given below provides us with the graphical representation of these calculation's results. In accord with the methodology employed, values of VRC $>0$ reveal a comparative advantage; correspondingly negative values reveal a comparative disadvantage.

According to Volltath index, revealed competitiveness of Agricultural products was not recorded, in contrast to Balassa RCA, at all. The entire analyzed period all values of VRC index for Agricultural products were negative, thus revealing a comparative disadvantage of Russian agro-producers in external markets. However, it should be noted that the dynamics of VRC index for Agricultural products demonstrated an upward trend in relation to agro-producers from BRICS. The upward dynamics of VRC indices was also observed for the following commodity groups: Fuels and Mining Products (except CIS, the VRC index values in relation to which were more or less stable), Iron and Steel (in relation to CIS only). Despite a sharp increase in VRC index for Russian Textiles was observed in 2014, the overall dynamics of VRC index values had a downward slope in relation to all four foreign trade partners. Volltath revealed competitiveness was recorded for the following groups of commodities only: Fuels and mining products (during the entire analyzed period and in relation to all four groups of partners); Iron and Steel (during the entire analyzed period in relation to EU, CIS and All trade partners, however in relation to BRICS after 2011 VRC reveal a comparative disadvantage); and Chemicals (during the period from 2000 to 2009 and in relation to BRICS and in 2002, 2013, 2014 in relation to CIS). Similarly, the position of Agricultural Products in comparison to other groups of commodities in corresponding external markets, expressed by VRC index on average, appeared in fourth place after Fuels and Mining Products, Iron and Steel and Chemicals.

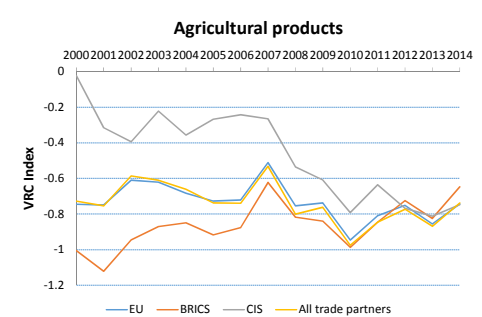

Chemicals

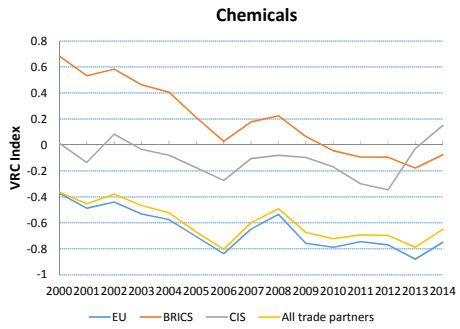

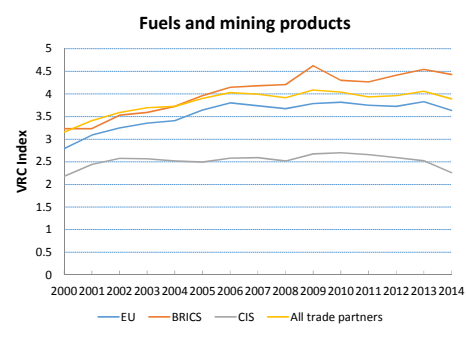

Machinery and transport equipment
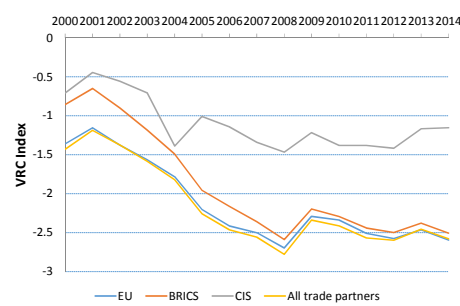

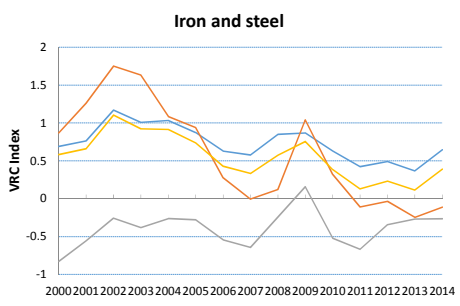

—EU — BRICS —CIS —All trade partners

Textiles

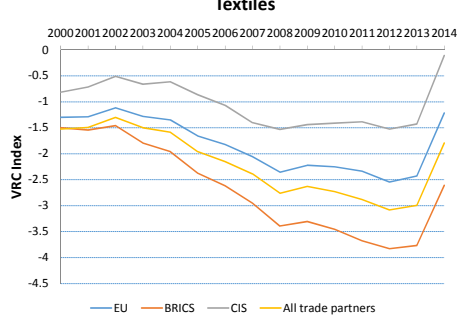

Figure 3. Vollrath index by commodity groups and groups of trade partners (2000-2014). Source: Author's calculation, raw data from: http://stat.wto.org/ [32].

Finally, the Lafay indices were calculated for the same as above groups of commodities, but in relation to all trade partners only (the list of them is given in the Table A1). Employing Equation (20) we obtained the result depicted in the Figure 4. If LFI > 0 then, in accord with the methodology, it indicates the existence of comparative advantages in a given commodity. Moreover, the larger the LFI value is, the higher is the degree of specialization, while negative values point to de-specialization in trade with corresponding sector's commodities.

In Figure 4, we can see that LFI values for Agricultural Products are negative through the entire analyzed period, pointing to de-specialization of Russian foreign trade with corresponding 
sector's commodities during this period of time. Nevertheless, the upward dynamics was observed. It implies that the degree of Russia's foreign trade specialization in agro-products has increased (however slightly) during the period from 2000 to 2014. The positive and simultaneously high values of LFI are observed only for Fuels and Mining Products, indicating the degree of specialization of Russian producers in this sector. Values that are slightly above zero belong to Iron and Steel commodity group. LFI indices for other commodity groups are negative throughout the entire analyzed period. The upward dynamics of LFI values was observed for Fuels and Mining products as well as for Agricultural Products. The LFI values for the rest commodity groups demonstrated downward trend. The most significant de-specialization of Russian producers was recorded in Machinery and Transport Equipment. The position of agro-producers relatively to other selected groups of commodities' producers, expressed by LFI index, is here worse than in the previous cases (RCA and VRC). Agricultural Products are now on the fifth place after Fuels and Mining Products, Iron and Steel, Textiles and Chemicals.

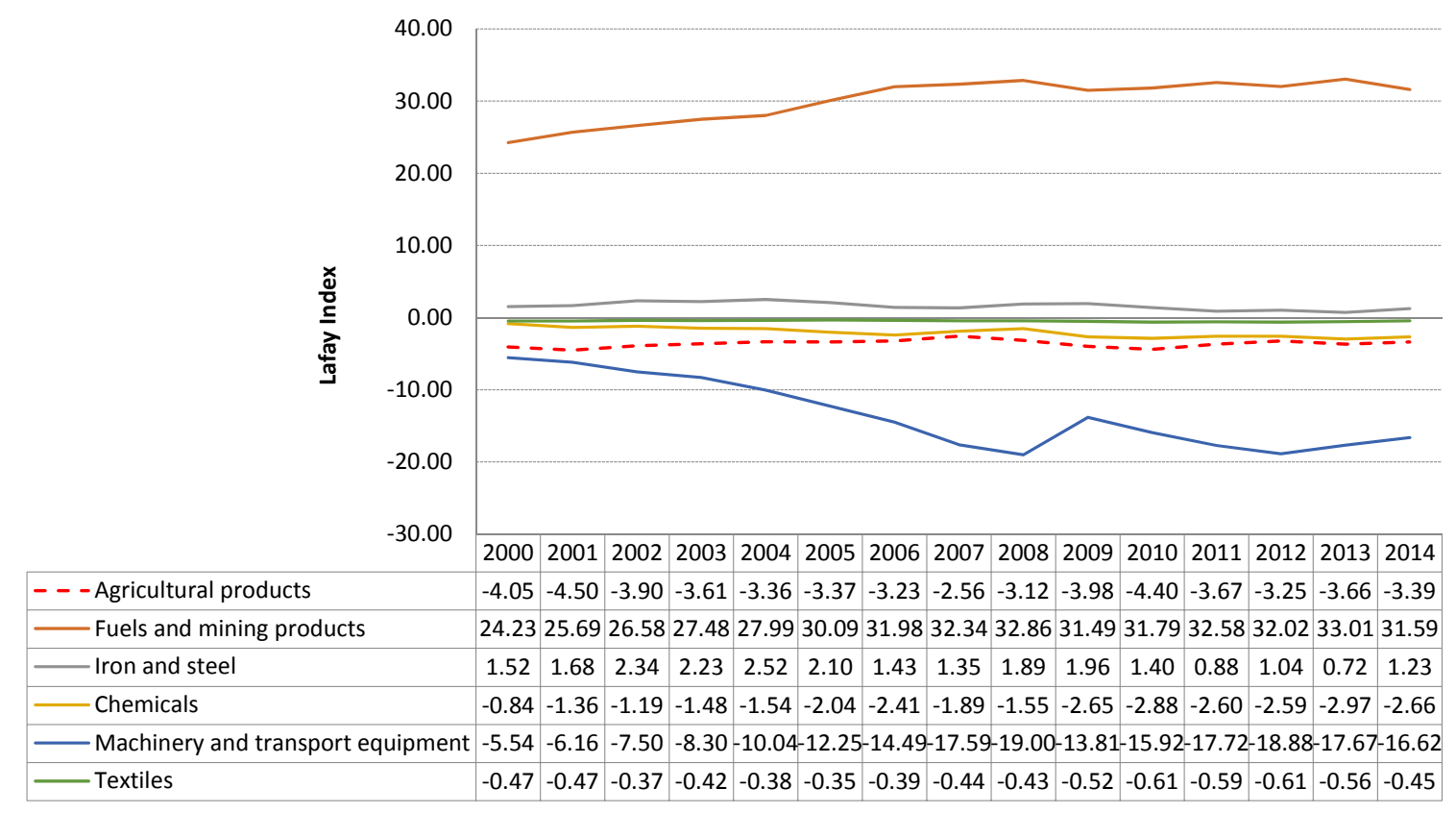

Figure 4. Lafay RCA index by commodity groups in dynamics (2000-2014). Source: Author's calculation, raw data from: http://stat.wto.org/ [32].

As a result, high values of all three indices (RCA, VRC and LFI) are observed for Fuels and Mining Products only. Nevertheless, comparative advantage of Russian Iron and Steel exports also appeared as revealed in relation to EU, BRICS and All trade partners, but in relation to CIS group RCA index was during the all analyzed period below the unity, thus demonstrating a comparative disadvantage. The summary table of the calculation results of all the indices for all trade partners and all types of commodity groups is given in Table 4.

As we can see from the pivot Table 4, Russian producers' position in corresponding external markets can be characterized as competitive only in terms of raw materials and products with relatively low degree of processing. Neither light manufacturing nor heavy industry reveals a sustainable comparative advantage during the analyzed period. It should be noted that Arms industry was not included into the analysis due to issues of data availability and compatibility with the available data for other countries included into the analysis. Regardless, the absence of comparative advantage, nevertheless positive dynamics (that is increasing trend in the values of some indices), is observed for the following groups of commodities: Agricultural Products in relation to BRICS (RCA and VRC indices), Chemicals in relation to CIS (RCA and VRC indices), and Iron and steel in relation to CIS (VRC 
index). A slight increase of Russian producers' international specialization in Agricultural Products is confirmed by positive dynamics of LFI values.

The entire analyzed period (from 2000 to 2014) can be characterized on average as the period of the real appreciation of the Russian rouble (see Figure 1). In connection to this, as can be expected, the current position (in 2014) of Russian producers both in external and internal markets has become on average less competitive than in 2000. At the same time, during the periods from 2008 to 2009 and in 2014, short-term real depreciations of RUR were observed. As is well known, depreciation of the national currency is supposed to influence positively the competitiveness of domestic products in external markets (Klvačová, 2005 [11]). However, calculations of RCA, VRC and LFI indices for the selected key commodity groups in the Russian economy have not proven this. The most intuitive juxtaposition analysis of all the obtained results let us to conclude that, contrary to popular belief, devaluation of RUR did not lead to an immediate increase in domestic producers' competitiveness both in external and internal markets.

Table 4. Summary table of the RCA, VRC and LFI indices values in relation to all groups of foreign trade partners for the period from 2000 to 2014.

\begin{tabular}{|c|c|c|c|c|}
\hline $\begin{array}{c}\text { Comparative } \\
\text { Advantage is Revealed }\end{array}$ & EU & CIS & BRICS & All Trade Partners \\
\hline \multicolumn{5}{|c|}{ Agricultural Products } \\
\hline RCA $>1$ & $\mathrm{NO}$ & $\mathrm{NO}$ & YES $(2006,2007,2009)^{1}$ & NO \\
\hline $\mathrm{VRC}>0$ & $\mathrm{NO}$ & $\mathrm{NO}$ & NO & $\mathrm{NO}$ \\
\hline LFI $>1$ & - & - & - & NO \\
\hline \multicolumn{5}{|c|}{ Fuels and Mining Products } \\
\hline RCA $>1$ & YES & YES & YES & YES \\
\hline $\mathrm{VRC}>0$ & YES & YES & YES & YES \\
\hline LFI $>1$ & - & - & - & YES \\
\hline \multicolumn{5}{|c|}{ Iron and Steel } \\
\hline $\mathrm{RCA}>1$ & YES & $\mathrm{NO}$ & YES & YES \\
\hline VRC $>0$ & YES & YES (2009) & YES (2000-2010) & YES \\
\hline LFI $>1$ & - & - & - & YES \\
\hline \multicolumn{5}{|c|}{ Chemicals } \\
\hline $\mathrm{RCA}>1$ & NO & YES (2014) & YES & NO \\
\hline $\mathrm{VRC}>0$ & & YES $(2000,2002,2014)$ & YES (2000-2009) & \\
\hline $\mathrm{LFI}>1$ & - & - & - & NO \\
\hline \multicolumn{5}{|c|}{ Machinery and Transport Equipment } \\
\hline RCA $>1$ & $\mathrm{NO}$ & NO & $\mathrm{NO}$ & $\mathrm{NO}$ \\
\hline $\mathrm{VRC}>0$ & $\mathrm{NO}$ & $\mathrm{NO}$ & NO & $\mathrm{NO}$ \\
\hline LFI > 1 & - & - & - & NO \\
\hline \multicolumn{5}{|c|}{ Textiles } \\
\hline $\mathrm{RCA}>1$ & $\mathrm{NO}$ & NO & $\mathrm{NO}$ & $\mathrm{NO}$ \\
\hline $\mathrm{VRC}>0$ & $\mathrm{NO}$ & NO & NO & $\mathrm{NO}$ \\
\hline LFI > 1 & - & - & - & $\mathrm{NO}$ \\
\hline
\end{tabular}

Note: ${ }^{1}$ figures in parentheses imply years in which corresponding comparative advantage index is revealed, for other years there is NO comparative advantage. Source: Author's calculation.

\section{Conclusions}

The main aim of the present paper was to investigate the position of Russian Agrarian Producers both in comparison to domestic producers from other sectors and in relation to its main foreign competitors in external and internal markets. Analysis of the recent dynamics of the real effective exchange rate of Russian rouble (from 2000 to 2014) served in the present paper as a macro-indicator reflecting a short-run price competitiveness, which determines relative position of domestic producers in external markets. The actual long-run position of domestic producers in corresponding external markets was reflected by Balassa, Vollrath and Lafay indices of the key commodity groups of the 
Russian Federation's foreign trade flows. The logic behind applying all three indices simultaneously was that each of them reflects different aspects of competitiveness. Balassa index, dealing with export flows, reveals absolute comparative advantage of a country in its foreign trade; Vollrath index, taking into account not only exports but also imports flows, reveals in turn relative comparative advantage; and Lafay index, calculation of which being based on overall normalized trade balance, points to a country's observed foreign trade specialization. Internal market position was represented in the present study by market share of Russian producers in domestic markets.

Based on the research findings the following conclusions can be stated. The entire analyzed period can be characterized on average as a period of significant real appreciation of the Russian rouble. The main reason behind this is the difference in inflation rates in Russia and its main foreign trade partners. Nominal exchange rate fluctuations affected REER to a much lower extent than the inflation rate did. The roots of the growing inflation rate in Russia are connected to the Dutch disease problem, which is indirectly confirmed by decreasing volumes of industrial manufacturing in almost all sectors (naturally, except Mineral Products) in comparison to average growth rates of corresponding imports (see Table 3). Among negative consequences, which the REER appreciation entails, is primarily weakening of industrial competitiveness along with further upward pressure on inflation rate in the country. This, as expected, should predetermine relatively low price competitiveness of domestic producers. On the other hand, the adoption of the national project "Development of Agricultural Complex" (2006-2007), the Food Security Doctrine of the Russian Federation (2010) and Russia's accession to the World Trade Organization (2012) established a new formal framework for agricultural business, created a space for emerging possibilities to change the situation in the country's agriculture.

Further analysis conducted on the agro-producers' competitive position has shown some discrepant results. Despite the fact that growth rates of agro-imports exceeded growth rates of agro-production, "Foodstuffs and Agricultural Raw Materials (Except Textile)", that is namely agro-producers, showed relatively good results in comparison to producers from other sectors. In other words, the position of agro-producers among other selected sectors' producers in domestic markets is one of the best after Mineral Products. The position of Russian agro-producers in domestic markets towards to its foreign competitors was then estimated as their market share. The calculations shown that estimated shares of domestic agro-producers in internal markets were during the all analyzed period almost the same what reveals their relatively stable position (values of market shares fluctuated between $76 \%$ and $74 \%$ ).

With regard to external markets, in accordance with RCA (Balassa) index, the position of Russian agro-producers in comparison to other Russian producers appeared not as favorable as it is in internal markets, agro-producers are on the fourth place after Fuels and mining products, Iron and Steel and Chemicals. In comparison to its foreign rivals Russian agro-producers enjoyed revealed comparative advantage in relation to BRICS group only: RCA index was greater than unity in 2006, 2007 and 2009 , very close to unity values were achieved in 2002, 2003 and 2014. Relative to the rest of Russia's trade partners (EU, CIS and All trade partners), Russian agrarian export demonstrated a comparative disadvantage; moreover, the dynamics of the RCA index revealed here a negative trend. According to Volltath index, revealed competitiveness of Agricultural Products was not recorded at all. Through the entire analyzed period all values of VRC index for Agricultural Products were negative revealing, thus, a comparative disadvantage of Russian agro-producers in external markets. However, it should be noted that the dynamics of this index demonstrated an upward trend in relation to agro-producers from BRICS group. The LFI values for Agricultural Products appeared negative through the entire analyzed period, pointing to de-specialization of Russia in Agrarian foreign trade. Nevertheless, the upward dynamics was observed. It implies that the degree of Russia's foreign trade specialization in agro-products has increased (however slightly). The position of agro-producers relatively to other selected groups of commodities' producers, expressed by LFI index, was here worse than in the previous cases (RCA and VRC indices). Agricultural Products appeared in fifth place after Fuels and Mining Products, Iron and Steel, Textiles and Chemicals. 
The analysis has shown that significantly appreciated rouble supports theoretical concepts regarding its negative impact on domestic producers' competitiveness: the absolute majority of calculated indices point to a decrease in the competitiveness of all selected for the analysis groups of products (except Mineral Products). At the same time, the short-term real depreciations of rouble did not have any expected substantially positive impact on competitive position of agrarian as well as other producers in Russia. The most intuitive juxtaposition analysis of all the obtained results let us conclude that, contrary to popular belief, devaluation of RUR did not lead to an immediate increase in domestic producers' competitiveness, both in external and internal markets. Although, taking into the account the fact that the periods of real depreciation of Russian rouble were not continuous, the possible beneficial effect on Russian producers' competitiveness may not be observable by the selected indices directly. It can be partially explained, for example, by a consequence of lags in the producers' reaction to the exchange rate fluctuations or even by their actual inability to react flexibly. For that reason, to investigate Russian producers' price competitiveness more deeply, further analysis of the selected indicators' interrelations can be suggested with the use of VAR model that has proven to be especially useful for describing the dynamic behavior of macroeconomic and financial time series. The possibility of combining long-run and short-run information in the data by exploiting the co-integration property (VECM) is the most important reason why VAR/VECM model will be utilized in a prospective research.

Acknowledgments: This article was prepared on the materials of the research project "Vybrané aspekty ekonomických sankcí a jejich dopady na vzájemný obchod EU-Rusko" (Selected aspects of economic sanctions and their impact on trade between EU-Russia) performed within the internal grant No. 20151031, provided by the Internal Grant Agency of the Faculty of Economics and Management, Czech University of Life Sciences Prague.

Author Contributions: Elena Kuzmenko contributed to data collection, conceived and designed the experiments, as well as interpreted the results; Mansoor Maitah contributed to the analysis of the estimation results; Lubos Smutka provided analytical materials and methodological tools; Maitah, M. and Kuzmenko, E. wrote the manuscript. All authors read and approved the final manuscript.

Conflicts of Interest: The authors declare no conflict of interest.

\section{Appendix A}

Table A1. Selected key trade partners ${ }^{1}$ of the Russian Federation.

\begin{tabular}{cr}
\hline Economic/Regional Unions & Countries (LCU) \\
European Union, EU & $\begin{array}{c}\text { Germany (EUR), Netherlands (EUR), Spain (EUR), Austria (EUR), } \\
\text { Finland (EUR), Italy (EUR), Sweden (EUR), France (EUR), Poland } \\
\text { (PLN), United Kingdom (GBP), Czech Republic (CZK). }\end{array}$ \\
\hline BRICS & Brazil (BRL), India (INR), China (CNY), Africa (ZAR). \\
\hline Commonwealth Independent States, CIS & Belarus (BYR), Ukraine (UAH), Kazakhstan (KZT), Armenia (AMD). \\
\hline Asia-Pacific Economic Cooperation, APEC & USA (USD), Japan (JPY), South Korea (KRW). \\
\hline Note: ${ }^{1}$ accordingly to total trade flows during the period from 2000 to 2013. Source: Author's processing.
\end{tabular}

\section{References}

1. Shkarupa, E.A. Razvitie gosudarstvennoy podderzhki selskogo hozjaistva (Development of the state support to agriculture). Bull. Volgogr. State Univ. Ser. 3 Econ. Ecol. 2010, 2, 84-88.

2. Batmanova, V.V.; Mitrofanova, I.V.; Ivanov, N.P.; Kotova, L.A.; Shkarupa, E.A. Agricultural Machinery in Russia: Risks and Prospects of the Development within the WTO (Сельскохозяйственное машиностроение в России: риски и перспективы развития в рамках ВТО). Pensee J. 2014, 76, 78-86.

3. Gaddy, C.G. Perspectives on the Potential of Russian Oil. Eur. Geogr. Econ. 2004, 45, 346-351. [CrossRef]

4. Kuboniwa, M. Growth and diversification of the Russian economy in light of Input-Output tables. J. Econom. Study Northeast Asia 2011, 7, 1-16.

5. Barsukova, S. Russian Agrocomplex: Reality and Future. Univ. Russ. 2013, 22, 3-28. (In Russian) 
6. Maitah, M.; Smutka, L. Restoration and Growth of the Russian Sugar Market. Sugar Tech. 2016, 2, 115-123. [CrossRef]

7. Smutka, L.; Zhuravleva, E.; Pulkrabek, J.; Benesova, I.; Maitah, M. Russian Federation- Sugar Beet and Sugar Production. Listy Cukrovarnicke a Reparske 2015, 2, 72-77.

8. Maitah, M.; Rezbova, H.; Smutka, L.; Tomsik, K. European Sugar Production and its Control in the World Market. Sugar Tech. 2016, 3, 236-241. [CrossRef]

9. Boltho, A. The assessment: International competitiveness. Oxf. Rev. Econ. Policy 1996, 12, 1-16. [CrossRef]

10. Lall, S. Competitiveness indices and developing countries: An economic evaluation of the Global Competitiveness Report. World Dev. 2001, 29, 1501-1525. [CrossRef]

11. Klvačová, E. Měření konkurenceschopnosti zemí: Teoretické základy a praktické výsledky. Acta Econom. Prag. 2005, 2. Available online: https://www.vse.cz/aop/175 (accessed on 8 August 2015). [CrossRef]

12. Ajevskis, V.; Rimgailaite, R.; Rutkaste, U.; Tkacevs, O. The equilibrium real exchange rate: Pros and cons of different approaches with application to Latvia. Balt. J. Econ. 2014, 14, 101-123. [CrossRef]

13. Kudrin, A. Realniy effektivniy kurs rublya: Problemy rosta (The real effective course of rouble: The problems of growth). Vopr. Ekon. 2006, 10, 4-18.

14. Sanidas, E.; Shin, Y. Comparison of Revealed Comparative Advantage Indices with Application to Trade Tendencies of East Asian Countries. 2010. Available online: http://www.akes.or.kr/eng/papers(2010)/24. full.pdf (accessed on 25 December 2015).

15. Ballance, R.H.; Forstner, H.; Murray, T. Consistency tests of alternative measures of comparative advantage. Rev. Econ. Stat. 1987, 69, 157-161. [CrossRef]

16. Panilov, M. Raschet i analiz dinamiki realnogo effektivnogo kursa rublya (Calculation and the analysis of the real effective rouble exchange rate dynamics). Audit Finans. Anal. 2009, 2. Available online: http: //www.auditfin.com/fin/2009/2/Panilov/Panilov\%20.pdf (accessed on 13 August 2015).

17. Blank, A.; Gurvich, E.; Ulyukaev, A. Exchange Rate and Competitiveness of Russia's Industries. Vopr. Ekon. 2006, 6, 4-24.

18. Bender, S.; Li, K.W. The Changing Trade and Revealed Comparative Advantages of Asian and Latin American Manufacture Exports. Yale University, Economic Growth Center Discussion Paper No. 843. 2002. Available online: http://www.econ.yale.edu/growth_pdf/cdp843.pdf (accessed on 12 December 2015).

19. Balassa, B. Trade Liberalisation and "Revealed" Comparative Advantage. Manch. Sch. 1965, 33, 99-123. [CrossRef]

20. Svatoš, M.; Smutka, L. Development of Agricultural Trade of Visegrad Group Countries in Relation to EU and Third Countries. Agris On-Line Pap. Econ. Inform. 2012, 4. Available online: http://online.agris.cz/files/ 2012/agris_on-line_2012_3_svatos_smutka.pdf (accessed on 8 August 2015).

21. Vollrath, T. A theoretical evaluation of alternative trade intensity measures of revealed comparative advantage. Rev. World Econ. 1991, 127, 265-280. [CrossRef]

22. Lafay, G. The Measurement of Revealed Comparative Advantages; Dagenais, M.G., Muet, P.-A., Eds.; Chapman \& Hall: London, UK, 1992.

23. Smutka, L.; Maitah, M.; Zhuravleva, E.A. The Russian Federation-Specifics of the Sugar Market. Agris On-Line Pap. Econ. Inform. 2014, 6, 73-86.

24. Zaghini, A. Trade advantages and specialization dynamics in acceding countries. Eur. Cent. Bank Work. Pap. 2003, 4-15. Available online: https://www.ecb.europa.eu/pub/pdf/scpwps/ecbwp249.pdf? 4ed34bff923d6655e2de4fc12eb144c1 (accessed on 26 December 2015).

25. Moscow Interbank Currency Exchange. Historic Exchange Rates. August 2015. Available online: https://www.micex.ru/marketdata/quotes?group=currency_selt\&data_type=history / (accessed on 14 August 2015).

26. Statbureau. Eurozone Inflation Rate. Available online: https://www.statbureau.org/ru/eurozone/inflation/ 2015 (accessed on 14 August 2015).

27. Statbureau. Inflation Rate in Russia. Available online: https://www.statbureau.org/en/russia/inflation (accessed on 14 August 2015).

28. All-Russian Market Research Institute. Foreign Exchange Policy and the Exchange Rate Performance. Available online: http://www.afrocom.ru/en/russia_outlook/economy (accessed on 8 August 2015). 
29. The Central Bank of the Russian Federation (Bank of Russia). Information Notice: On Parameters of Bank of Russia Exchange Rate Policy. November 2014. Available online: http://www.cbr.ru/eng/press/PR.aspx? file=10112014_122958eng_dkp2014-11-10T12_26_04.htm (accessed on 9 August 2015).

30. Brodsky, B. O vliyanii realnogo obmennogo kursa rublya na rossiyskuu ekonomiku (The Influence of the Ruble Real Exchange Rate on the Russian Economy). Prikl. Ekon. 2006, 4, 90-104.

31. Federal State Statistics Service. National Accounts. June 2015. Available online: http:/ /www.gks.ru/wps/ wcm/connect/rosstat_main/rosstat/ru/statistics/accounts/\# (accessed on 13 August 2015).

32. The World Trade Organization's Statistics Database. International Trade in Merchandise Data. Available online: http://stat.wto.org/StatisticalProgram/WSDBViewData.aspx?Language=E (accessed on 13 August 2015).

33. Federal Customs Service. Foreign Trade of the Russian Federation. No Date. Available online: http: / / www.customs.ru/index.php?id=13858\&Itemid=2095\&option=com_content (accessed on 08 August 2015).

34. Domnich, E.L. Ekonomicheskoe polozhenie otrasley mashinostroeniya Dalnevostochnogo Federalnogo okruga v 2008-2009 (Economic situation of machinery industry in the Far Eastern Federal District in 2008-2009). Prostranstv. Ekon. 2011, 2, 146-168.

(c) 2016 by the authors; licensee MDPI, Basel, Switzerland. This article is an open access article distributed under the terms and conditions of the Creative Commons Attribution (CC-BY) license (http:/ / creativecommons.org/licenses/by/4.0/). 